The 28th Lung Cancer Workshop

気管支鏡診断ナビゲーション

\author{
浅野文祐1
}

\title{
Navigation for Diagnostic Bronchoscopy
}

\author{
Fumihiro Asano1 \\ ${ }^{1}$ Department of Pulmonary Medicine, Gifu Prefectural General Medical Center, Japan.
}

ABSTRACT — Transbronchial biopsies are often employed to definitively diagnose peripheral pulmonary lesions. Although this technique is associated with fewer complications than percutaneous biopsies, the diagnostic yield is low and the method requires the bronchoscopist to guide the bronchoscope and biopsy instruments to the lesion. Virtual bronchoscopic navigation (VBN), an exclusive system of which is now commercially available, can be used to guide the bronchoscope to peripheral lesions under direct visualization using virtual bronchoscopy images of the bronchial route. VBN is applied in combination with CT-guided ultrathin bronchoscopy, endobronchial ultrasonography with a guide sheath (EBUS-GS) and fluoroscopy- and non-fluoroscopy-assisted bronchoscopy, with a reported rate of diagnosis of peripheral pulmonary lesions and tumors measuring $2 \mathrm{~cm}$ or smaller of $74 \%$ and $67.5 \%$, respectively. In a randomized controlled study, the combination of VBN and EBUS-GS increased the diagnostic yield, while that combined with ultrathin bronchoscopy improved the rate of diagnosis of lesions located in the right upper lobe or peripheral third of the lung field and those invisible on posterior-anterior radiographs, according to a subanalysis. In order to increase the diagnostic yield of VBN, it is important to clarify the relationship between the lesion and the extracted bronchus used to construct virtual bronchoscopic images on $\mathrm{CT}$ and select the appropriate combination bronchoscopy procedure. VBN is a useful method for supporting bronchoscopy whose further spread and advancement is desirable.

(JJLC. 2014;54:843-847)

KEY WORDS - Virtual bronchoscopic navigation, Endobronchial ultrasonography with a guide sheath, Navigational bronchoscopy, Ultrathin bronchoscopy, Peripheral pulmonary lesion

Reprints: Fumihiro Asano, Department of Pulmonary Medicine, Gifu Prefectural General Medical Center, 4-6-1 Noishiki, Gifu 5008717, Japan (e-mail: asano-fm@ceres.ocn.ne.jp).

要旨一一肺末梢病変の確定診断として経気管支生検は, 経皮生検より合併症が少ないが, 診断率が低く, 気管支 鏡や生検器具を病変に誘導することが重要である，仮想 気管支鏡ナビゲーション（virtual bronchoscopic navigation, VBN) は，末梢病変への気管支ルートの仮想気管支 鏡画像を使って，直視下に気管支鏡を誘導する方法で， 専用のシステムが市販されている. VBN は CT ガイド下 極細径気管支鏡検査, ガイドシース併用気管支腔内超音 波断層法 (EBUS-GS), X 線透視および非 X 線透視下気管 支鏡と併用され，肺末梢病変に対する診断率は $74 \%, 2$ $\mathrm{cm}$ 以下の病変では $67.5 \%$ と報告されている．ランダム 化比較試験において, EBUS-GS との組み合わせで VBN
は診断率を向上させること，X 線透視下極細径気管支鏡 では, サブクラス解析で右上葉, 肺野外層に位置する,

$\mathrm{X}$ 線透視で見えない病変で診断率を向上させることが示 された. VBNの診断率を上げるためは, CT で病変と仮 想気管支鏡像の基となる抽出された気管支の関係を把握 し，適切な気管支鏡検査手技と組み合わせることが大切 である.VBN は気管支鏡検査をサポートする有用な方法 であり，さらなる普及とシステムの進化が望まれる．

索引用語——仮想気管支鏡ナビゲーション, ガイドシー ス併用気管支腔内超音波断層法, 気管支鏡ナビゲーショ ン, 極細径気管支鏡, 肺末梢病変 


\section{末梢小型病変の生検}

CT の普及により，日常診療で末梢小型病変に遭遇す る機会が増えている。これらの病変の多くは良性病変で あるが，その中から早期の肺癌を見つけ出すことが重要 である. ${ }^{1}$ 肺癌の診断は病変から検体を採取して, 病理診 断することがゴールドスタンダードであり，そのための 方法として外科的生検, 経皮針生検, 経気管支生検が選 択される. 外科的生検は最も確実な方法であるが，全身 麻酔や片肺換気を必要とし患者への負担が大きい。ささら に病変が小型である場合は，切除が必要でない良性病変 である可能性も高い. 経皮針生検の診断感度は, CT の使 用, 病変のサイズ，良性疾患か悪性疾患かで異なるが, American College of Chest Physicians (ACCP) のガイド ラインでは感度 $90 \%$, 特異度 $97 \%$ と報告されている. ${ }^{2}$ しかし, 合併症の頻度は高く, 日本の CT ガイド下針生検 調査では, 9,783 件中, 死亡率 $0.07 \%$, 重症合併症発生率 (緊張性気胸, 血気胸, 空気塞栓, 播種) $0.75 \%$, 気胸発生 率 $35 \%$ と報告されている. ${ }^{3}$ 一方，経気管支生検の合併 症に関しては, 日本呼吸器内視鏡学会の調査では, 2010 年 1 年間に施行された 37,485 件中, 死亡率は $0.003 \%$, 全 合併症率は $1.79 \%$ （出血 $0.73 \%$, 気胸 $0.63 \%$ ）であった. ${ }^{4}$ このように合併症が少ないこともあり，日本では末梢病 変に対しては気管支鏡検査がファーストチョイスされて いるが, 診断率は不充分で, ACCP のガイドラインによ ると $2 \mathrm{~cm}$ 以下の病変では $34 \%$ と報告されている. ${ }^{2}$

\section{経気管支診断}

肺末梢病変の経気管支診断には主に病変側の要因とし て, サイズ，存在部位，関与気管支の有無，悪性疾患か 良性疾患か, $5-7$ 術者側の要因として使用する機器, 術者 の技術, 経験8 などが挙げられる. 現在, 肺末梢病変に行 われる気管支鏡検査は, 外径 5 $6 \mathrm{~mm}$ 程度の気管支鏡を 使用してX 線透視下で行われている. 特に経気管支生検 の重要な問題点として，気管支鏡や生検器具の病変への 誘導が難しいことが挙げられる，末梢病変に到達するた めには, 数多くの気管支分岐部を経て, 病変に到達する 気管支に正しく気管支鏡や生検器具を誘導させることが 必要である。このために気管支鏡医は，通常，検査前に 撮影した CT の axial 画像を参考にして病変への気管支 ルートを推定する．最近は画像モニター上でこれらの画 像をスクロールしながら観察し，頭の中で気管支走行を 3 次元的に構築している. しかしこの方法は $3 \sim 4$ 次気管 支レベルでも不正確であり,9 害際に気管支鏡を挿入す ると，気管支分岐が事前の予想と違う場合も多い。また， 細径あるいは極細径気管支鏡の抻入や観察範囲の，末梢 の気管支レベルには充分に対応できない，そのため末梢
病変に対する気管支鏡では, 何らかの病変へのナビゲー ション方法が望まれていた.この問題を解決するために, 近年注目されているのが気管支鏡ナビゲーション（navigational bronchoscopy) である. 気管支鏡ナビゲーション は, CT から得られる各種 3 次元表示デー夕を, 気管支鏡 検查中に得られる実際の患者情報と相互に関連させて, 気管支鏡や検体採取器具を誘導する方法である. 現在, 国内外の臨床で使用されている気管支鏡ナビゲーション は仮想気管支鏡ナビゲーション（virtual bronchoscopic navigation, VBN) と電磁ナビゲーション (electromagnetic navigation, EMN)で，それぞれ専用のシステムが 市販されている. 両者は, 3 次元 CT 表示, 特に仮想気管 支鏡を使用する点では類似しているが，仮想画像の使用 法が異なり，さらに EMN では電磁センサーを使用する 点で異なっている.10 EMN は日本では導入されていな いので，本稿ではVBN について述べる.

\section{仮想気管支鏡ナビゲーション（VBN）}

仮想気管支鏡（virtual bronchoscopy）はヘリカル CT で撮影された 3 次元デー夕を基に，気管支鏡で観察され たような気管支内腔画像を作成する方法である．非侵襲 的であることから中枢気道狭窄の評価, 治療に応用され てきたが, 11 これまで末梢病変には利用されていなかっ た. 仮想気管支ナビゲーション（virtual bronchoscopic navigation）とは，末梢病変への気管支ルートの仮想気管 支鏡画像を使って，直視下に気管支鏡を誘導する方法で ある. 12 市販の汎用画像作成ソフトウエアでも可能であ るが，気道壁と気道内腔を区別する閾值の設定が難しい ことや，気管支鏡の回転操作により実像が仮想画像と回 転した分だけずれるという問題点がある。これらの問題 を解決し，目標を設定するだけで自動で目標までの気管 支ルートを探し出して,ルート上の仮想画像を作成し, 13 実像に合わせて仮想画像を表示できる14 システム，BfNAVI $^{\circledR}$ （Cybernet System Inc., Tokyo, Japan）が 2008 年に日本で市販された。2009 年には米国で LungPoint ${ }^{\circledR}$ (Broncus Medical Inc., CA, USA）が市販され，その後, 米国では保険認可された. 現在日本, EUでも使用されて いる，両システムの概要は類似しているが，Bf-NAVI では，気管支鏡検查前に editor にCT-DICOM デー夕を 入力し，1）始点を設定し気管支を自動抽出，2）目標, 終点の設定でルートを自動検索, 3) 仮想画像の自動作成, 4）ルート確認とサムネール登録，の過程で病変までの ルートの仮想気管支画像を作成する，次に検查室に置い た viewer を使って，各気管支分岐で実像に仮想画像を 対比させながら，仮想画像上のルートに従い，気管支鏡 を誘導していく，両システムのそれぞれの利点は， BfNAVIでは，仮想気管支画像を作成する基となる気管支 
の抽出状態が確認でき, 抽出ができていないときは手動 で追加抽出ができる. 15 このため病変の近くまで仮想画 像を作成でき，ナビゲーション精度を上げることができ る. 一方 LungPoint は, 追加気管支抽出はできないが, 操作が簡便であり，海外のバージョンでは，仮想気管支 画像を実像とセミオートで対比できる．2010年の時点 で, 日本呼吸器内視鏡学会気管支鏡認定, および関連施 設の $13.1 \%$ が VBN システムを保有していた. 162014 年 現在, Bf-NAVI の後継として Directpath ${ }^{\circledR}$ (Cybernet System Inc., Tokyo, Japan) が中国で市販され, 日本でも 発売予定である。

\section{VBN の成績}

VBN は, CT ガイド下極細径気管支鏡検査, 14,17-19 ガ イドシース併用気管支腔内超音波断層法 (endobronchial ultrasonography with a guide sheath, EBUS-GS), 13,20,21 $\mathrm{X}$ 線透視 22 および非 $\mathrm{X}$ 線透視下気管支鏡 23 と併用され, 肺末梢病変に対する診断率は $74 \%, 2 \mathrm{~cm}$ 以下の病変で は $67.5 \%$ であった. $15 \mathrm{VBN}$ と CT ガイド下極細径気管 支鏡の組み合わせの診断率は $65.4 \sim 86.1 \%, 2 \mathrm{~cm}$ 以下の 病変に限ると 65.4 80.8\% で, 14,17-19 診断寄与因子は関 与気管支の有無と, 極細径気管支鏡検査の挿入範囲と報 告されている. 24 極細径気管支鏡は検体採取量が少ない ので, 細胞診を併用することが大切である. VBN と EBUS-GS の組み合わせの診断率は 63.3〜 84.4\%, $2 \mathrm{~cm}$ 以下の病変に限ると $44.4 \sim 73.3 \%$ と高率である. $13,20,21$ この方法は透視で見えない病変にも対応でき，ガイド シースにより病変部位から繰り返して正確に検体を採取 できる利点がある.しかしながらこれらの報告の多くは, プロスペクティブデザインであるが, 症例数が限られた 単一施設でのスタディである. VBN の有効性を客観的に

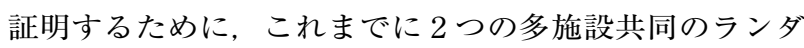
厶化比較試験が行われた. Ishida ら 21 は $3 \mathrm{~cm}$ 以下の肺末 梢病変 200 症例をVBNA（VBN-assisted）群, NVBNA (non-VBN-assisted) 群の 2 群に, 病変の大きさと術者を 考慮してランドマイズし, EBUS-GSを併用してX 線透 視下に生検を行った. VBNA 群では VBN システムを使 用し, NVBNA 群では CT の axial 像を参照して, 外径 4 $\mathrm{mm}$ の細径気管支鏡を誘導した. VBNA 群では仮想気管 支鏡画像は中央值 6 次気管支（範囲 4 12 次）まで作成 でき, 実像との一致度は $98 \%$ であった. VBNA 群の診断 率は $80.4 \%$ と, NVBNA 群の $67.0 \%$ に比較して有意に高 值であった $(\mathrm{p}=0.032)$.さらに生検開始までの時間，検 査時間も, VBNA 群で有意に短縮された. Asanoら25 は, $3 \mathrm{~cm}$ 以下の肺末梢病変 350 例を同様に 2 群にランド マイズし, VBNA群ではVBN システムを利用して, NVBNA 群では CT の axial 像を参照して, 外径 $2.8 \mathrm{~mm}$
の極細径気管支鏡を誘導した. 使用された極細径気管支 鏡の鉗子チャンネルは $1.2 \mathrm{~mm}$ と細いために EBUS プ ローブは挿入できないので, 両群ともにX 線透視下に生 検を行った. VBNA 群の診断率は $67.1 \%$ とVBNA 群 の 59.9\%より高かったが, 統計的な有意差は認めなかっ た $(\mathrm{p}=0.173)$. しかしサブクラス解析では, VBNA 群の 診断率は, 右上葉の病変 $(81.3 \%$ vs $53.2 \% \mathrm{p}=0.004)$, 肺 野外層に位置する病変 $(64.7 \%$ vs $52.1 \% \mathrm{p}=0.047), \mathrm{X}$ 線正面写真で見えない病変 $(63.2 \%$ vs $40.5 \% \mathrm{p}=0.043)$ で 有意に高率であった。このように VBN による診断率の 向上に関しては, EBUS-GS との組み合わせでは実証され たが, 極細径気管支鏡と X 線透視との組み合わせでは統 計学的には証明されなかった. しかしながら後者のラン ダム化比較試験では, サブクラス解析で VBN が有効な 群が推測されており, それらの群に属する病変の割合は 全体の 7 割強であった. 両者の結果からは, VBN は多く の症例に有用だが, すべての症例に必要なわけではない ことが推測され, 今後さらに有効な症例を選び出してい く必要がある.

Wang Memoli ら26 は2002 年から 2010 年までに行わ れた 39 スタディ, 3,004 患者, 3,052 病変を対象にイメー ジガイド気管支鏡（EMN，VBN，radial-EBUS，極細径 気管支鏡，ガイドシース）のメタアナリシスを行い，全 体の診断率は $70 \%$ であったと報告している.この中はレ トロスペクティブなスタディや, 縦隔, 肺門リンパ節も 対象としたスタディが含まれているが, VBN の診断率は $72.0 \%$, 95\% CI 65.7〜 78.4\% と報告されている.

\section{VBN の合併症}

合併症として $0.4 \%$ の気胸を認めているが従来の経気 管支生検と同様であり, VBN 自体によるものは特にな い. 15 また前述の 2 つのランダム化比較試験でも，いず れも VBN 使用により合併症の増加は認めなかった. ${ }^{21,25}$

\section{VBN の利点と問題点}

$\mathrm{VBN}$ の利点は，1）病変への気管支ルートがわかるた め, 気管支鏡の誘導が容易となり, 診断率が向上するこ と，2)気管支鏡の位置や進む方向を X 線透視などで確か める必要がないため, 誘導に要する時間を短縮できるこ と，3）合併症の増加がないこと，4） VBN システム以外 には，CT 撮影を除きコストがかからないこと，5）既存 の気管支鏡手技に追加するだけで，特別なトレーニング が不要であること，6)仮想画像の作成自体が気管支鏡検 査のシミュレーションとなるため, 教育的な効果も期待 できること, が挙げられる. 問題点としては, 適切な条 件での CT 撮影を要することが挙げられる。すなわち仮 想画像の作成は，基となる $\mathrm{CT}$ に依存する。このため 
$\mathrm{VBN}$ システムが推奨する CT 撮影条件, 特にスライス厚 は $1 \mathrm{~mm}$ 以下が望ましい.このため, 場合によっては CT の再撮影を要することがある．現在は，ほとんどの施設 がマルチスライス CTを使用しており，スライス厚 1 $\mathrm{mm}$ 以下で撮影することは難しくない. あらかじめ気管 支鏡，特に $\mathrm{VBN}$ を使用する予定の末梢病変症例では， CT 撮影後に $1 \mathrm{~mm}$ スライス以下で再構成しておくか, あるいは再構成できるように CT の生データを保管して おくことで, コストや被曝を要する CT 再撮影を防ぐこ とができる. CT で関与気管支が認められない場合でも, 病変に一番近接している気管支まで VBN により気管支 鏡を誘導できる.しかしその後の鉗子の病変への誘導が 難しい場合があり診断率も低い.このような症例には経 気管支針吸引生検が有効かも知れない. VBN の診断率を 上げるためには，CT で病変と仮想気管支鏡像の基とな る抽出された気管支の関係を把握し, 極細径気管支鏡や EBUS などの適切な気管支鏡検査手技を選択して VBN と組み合わせることが大切である.

\section{おわりに}

VBN はランドマイズスタディやメタアナリシスの結 果から, 診断率が向上, 検查時間が短縮されることが示 された．気管支鏡検査において VBN がどのような病変 に有効であるかを今後さらに，明確にする必要がある． VBN は気管支鏡検査をサポートする有用な方法であり， さらなる普及とシステムの進化が望まれる.

本論文内容に関連する著者の利益相反：なし

\section{REFERENCES}

1. Aberle DR, Adams AM, Berg CD, Black WC, Clapp JD, Fagerstrom RM, et al. Reduced lung-cancer mortality with low-dose computed tomographic screening. $N$ Engl J Med. 2011;365:395-409.

2. Rivera MP, Mehta AC, Wahidi MM. Establishing the diagnosis of lung cancer: Diagnosis and management of lung cancer, 3rd ed: American College of Chest Physicians evidence-based clinical practice guidelines. Chest. 2013;143(Suppl):e142S-e165S.

3. Tomiyama N, Yasuhara Y, Nakajima Y, Adachi S, Arai Y, Kusumoto M, et al. CT-guided needle biopsy of lung lesions: a survey of severe complication based on 9783 biopsies in Japan. Eur J Radiol. 2006;59:60-64.

4. Asano F, Aoe M, Ohsaki Y, Okada Y, Sasada S, Sato S, et al. Deaths and complications associated with respiratory endoscopy: a survey by the Japan Society for Respiratory Endoscopy in 2010. Respirology. 2012;17:478-485.

5. Chechani V. Bronchoscopic diagnosis of solitary pulmonary nodules and lung masses in the absence of endobronchial abnormality. Chest. 1996;109:620-625.

6. Baaklini WA, Reinoso MA, Gorin AB, Sharafkaneh A,
Manian P. Diagnostic yield of fiberoptic bronchoscopy in evaluating solitary pulmonary nodules. Chest. 2000;117: 1049-1054.

7. Naidich DP, Sussman R, Kutcher WL, Aranda CP, Garay SM, Ettenger NA. Solitary pulmonary nodules. CTbronchoscopic correlation. Chest. 1988;93:595-598.

8. Minami H, Ando Y, Nomura F, Sakai S, Shimokata K. Interbronchoscopist variability in the diagnosis of lung cancer by flexible bronchoscopy. Chest. 1994;105:16581662.

9. Dolina MY, Cornish DC, Merritt SA, Rai L, Mahraj R, Higgins WE, et al. Interbronchoscopist variability in endobronchial path selection: a simulation study. Chest. 2008;133:897-905.

10. Leong S, Ju H, Marshall H, Bowman R, Yang I, Ree AM, et al. Electromagnetic navigation bronchoscopy: A descriptive analysis. J Thorac Dis. 2012;4:173-185.

11. De Wever W, Vandecaveye V, Lanciotti S, Verschakelen JA. Multidetector CT-generated virtual bronchoscopy: an illustrated review of the potential clinical indications. Eur Respir J. 2004;23:776-782.

12. Asano F, Matsuno Y, Matsushita T, Kondo H, Saito S, Seko A, et al. Transbronchial diagnosis of a pulmonary peripheral small lesion using an ultrathin bronchoscope with virtual bronchoscopic navigation. J Bronchol. 2002;9: 108-111.

13. Asano F, Matsuno Y, Tsuzuku A, Anzai M, Shinagawa N, Yamazaki K, et al. Diagnosis of peripheral pulmonary lesions using a bronchoscope insertion guidance system combined with endobronchial ultrasonography with a guide sheath. Lung Cancer. 2008;60:366-373.

14. Asano F, Matsuno Y, Shinagawa N, Yamazaki K, Suzuki $\mathrm{T}$, Ishida $\mathrm{T}$, et al. A virtual bronchoscopic navigation system for pulmonary peripheral lesions. Chest. 2006;130: 559-566.

15. Asano F. Practical application of virtual bronchoscopic navigation. In: Mehta AC, Jain P, eds. Interventional Bronchoscopy - A Clinical Guide. New York: Humana Press; 2013:367-371.

16. Asano F, Aoe M, Ohsaki Y, Okada Y, Sasada S, Sato S, et al. Bronchoscopic practice in Japan: a survey by the Japan Society for Respiratory Endoscopy in 2010. Respirology. 2013;18:284-290.

17. Asano F, Kimura T, Shindou J, Matsuno Y, Mizutani H, Horiba M. Usefulness of CT-guided ultrathin bronchoscopy in the diagnosis of peripheral pulmonary lesions that could not be diagnosed by standard transbronchial biopsy. J Jpn Soc Bronchol. 2002;24:80-85.

18. Shinagawa N, Yamazaki K, Onodera Y, Miyasaka K, Kikuchi E, Dosaka-Akita H, et al. CT-guided transbronchial biopsy using an ultrathin bronchoscope with virtual bronchoscopic navigation. Chest. 2004;125:1138-1143.

19. Shinagawa N, Yamazaki K, Onodera Y, Asano F, Ishida $\mathrm{T}$, Moriya $\mathrm{H}$, et al. Virtual bronchoscopic navigation system shortens the examination time--feasibility study of virtual bronchoscopic navigation system. Lung Cancer. 2007;56:201-206.

20. Asahina H, Yamazaki K, Onodera Y, Kikuchi E, Shinagawa N, Asano F, et al. Transbronchial biopsy us- 
ing endobronchial ultrasonography with a guide sheath and virtual bronchoscopic navigation. Chest. 2005;128: 1761-1765.

21. Ishida T, Asano F, Yamazaki K, Shinagawa N, Oizumi S, Moriya $\mathrm{H}$, et al. Virtual bronchoscopic navigation combined with endobronchial ultrasound to diagnose small peripheral pulmonary lesions: a randomised trial. Thorax. 2011;66:1072-1077.

22. Tachihara M, Ishida $T$, Kanazawa K, Sugawara A, Watanabe K, Uekita K, et al. A virtual bronchoscopic navigation system under X-ray fluoroscopy for transbronchial diagnosis of small peripheral pulmonary lesions. Lung Cancer. 2007;57:322-327.

23. Eberhardt R, Kahn N, Gompelmann D, Schumann M,
Heussel CP, Herth FJ. LungPoint--a new approach to peripheral lesions. J Thorac Oncol. 2010;5:1559-1563.

24. Matsuno Y, Asano F, Shindoh J, Abe T, Shiraki A, Ando $\mathrm{M}$, et al. CT-guided ultrathin bronchoscopy: bioptic approach and factors in predicting diagnosis. Intern Med. 2011;50:2143-2148.

25. Asano F, Shinagawa N, Ishida T, Shindoh J, Anzai M, Tsuzuku A, et al. Virtual bronchoscopic navigation combined with ultrathin bronchoscopy. A randomized clinical trial. Am J Respir Crit Care Med. 2013;188:327-333.

26. Wang Memoli JS, Nietert PJ, Silvestri GA. Meta-analysis of guided bronchoscopy for the evaluation of the pulmonary nodule. Chest. 2012;142:385-393. 